\title{
Are There Nexus Between Public Expenditures and Economic Growth in Nigeria? - A Re- Examination
}

Anowor, Oluchukwu F. ${ }^{1}$

Nwanji, Michael O. ${ }^{2}$

\section{Department of Economics, Godfrey Okoye University, Enugu, Nigeria. \\ Email:oluchukwuanowor@gmail.com}

Licensed:

This work is licensed under a Creative Commons Attribution 4.0 License.

Keywords:

Public expenditures

Economic growth

Error correction model

Causality

Nexus.

JEL Classification:

H54O; H57O; O16; O47.

\begin{abstract}
Nigeria has been witnessing, for some three decades now, a rising trend in the size of her public expenditures and questions been raised on whether this upsurge could be related to economic growth. This study deliberately sets to re-examine the nexus between public expenditures and public expenditures in Nigeria adopting the Error Correction Model (ECM) estimation technique and the Pairwise Granger Causality test with disaggregated yearly data between 1980 and 2016. The findings suggested that the capital spending of the government has an inverse relationship with economic growth and also significant influence on economic growth. The government recurrent spending has a direct relationship with economic growth but statistically insignificant effects on economic growth. There is no causal relationship, as suggests by the result of the Granger Causality test, between public capital expenditure and economic growth. While there is existence of unidirectional causalities where exchange rate caused economic growth; economic growth caused private foreign investment; and economic growth caused public recurrent expenditure. The recommendations suggest that governments should make more provision for capital expenditures in the budget and ensure implementations are being properly monitored to ensure that the funds are not diverted to other uses; while cost of governance should be moderated with a view of making less provision for recurrent expenditure.
\end{abstract}

\section{Introduction}

Public expenditure is borne out of revenue allocations and is refers to, according to Okoro (2013) as the redistribution of fiscal capacity amongst the different levels of governments. It is prominently visible in all economies as an essential policy instrument to regulate political, social and economic pursuits. Expectantly, the size of public spending and the impact it has on economic growth has continued to generate debate among scholars with each scholar or group of scholars putting forward explanations to substantiate or oppose views. Conventionally, there are expectations that expansions in public spending on socio-economic and physical infrastructures should enhance growth and development of an economy. For instance, public expenditures on human capital (such as health and education) are anticipated to raise the output of labour and increase the growth of national output. Similarly, expenditures on infrastructures such as road, communication, power, and the likes are presumed will help reduce production cost, enhance private investment, and raise the profitability of firms, and consequently fostering economic growth. One of the primary intended aims of public sector investments is to ensure an economic climate in which the personnel needed to produce goods and services will be fully employed in various sectors of the economy (Onodugo, Obi, Anowor, Nwonye, \& Ofoegbu, 2017).

Within the Nigerian economy, government expenditure can be classified into capital and recurrent expenditures. The public capital expenditures are referred to as expenditure on projects such as roads, airports, health, education, telecommunication, electricity generation, etc.; while government recurrent expenditures are referred to as government overheads on administration such as: wages, salaries, interest on loans, maintenance, etc., Obinna (1985). The public sector, as noted in Ogunmuyiwa and Adelowokan (2015) expanded rapidly in Nigeria in the post-independence era following the massive intervention of the public sector in different facets of economic activities. It also continued to rise in the 1970 s as a result of the enormous income raised from production and sale of petroleum and increased demand for public goods (Okoro, 2013). As a result of this, public spending therefore became an avenue through which public goods could be provided to drive towards expansion of the industrial sector and creation of employment opportunities 
(Ogunmuyiwa \& Adelowokan, 2015). This perceived function of the public sector in the development process, as observed by Adubi and Obioma (1999) led to tremendous growth in public expenditures in Nigeria.

Some scholars opined that growth in government spending boosts economic growth. Scholars such as Ranjan and Sharma (2008), Cooray (2009) supported this view and concluded that enlargement of public spending contributes helpfully to economic growth. On the contrary, some scholars like Ladau (1983), Barro (1990), Engen and Skinner (1992) argued that higher government expenditure may slow down overall performance of the economy. They contended that in an attempt to finance rising expenditure, government may increase taxes and/or borrowing. Higher tax on income discourages workers from working for longer hours and even searching for jobs. This ultimately reduces income and aggregate demand. Similarly, higher profit taxes tend to build up production cost and reduce investment expenditure including profitability of firms. Increased government borrowing from the banks to finance its spending would also crowd-out private sector, thereby reducing private investment. Government officials and politicians often increase expenditures and investment on unproductive projects and on private goods. Government activity thus, sometimes results in misuse of resources thereby impeding growth of national output.

Statistics from the Central Bank of Nigeria indicates that total public (both recurrent and capital) expenditures have continued to increase over the years. Total capital expenditure increased from $\$ 10,163.4$ million in 1980 to $\$ 874,700$ million, $\$ 1,108,390$ million and $\$ 783,120$ million in 2012, 2013 and 2014 respectively. Correspondingly, total government recurrent expenditure increased from $\$ 4,805.2$ million in 1980 to $\$ 3,325,160$ million, $\$ 3214,950$ million and $\$ 3,426,940$ million in 2012,2013 and 2014 respectively. It is however becoming worrisome that the rising government expenditures are yet to translate into improving the basic macro-economic indicators. Okorie and Anowor (2017) observed that the sum of those in poverty trap in Nigeria has continued to increase same as the unemployment rates. Imagine the poverty incidence in Nigeria in 1980 was $28 \%$ and unemployment rate in same year $6.4 \%$; but both have jumped respectively to $64 \%$ and $25 \%$ by the end of 2016 despite the observed increase in public expenditures over these periods. Other depressing statistics on Nigeria showed that Human Development Index ranking for 2016-2017 was 152 out of 189 , inflation rate of $18.6 \%$, and Gini (inequality) index as at 2010 was 48.83 , while average life expectancy dropped from 53.05 years in 2015 to around 51 years in 2017.

It is against these back drops that this study is motivated to question the impact of public expenditures (disaggregated into recurrent and capital expenditures) on Nigeria's economic growth, and to ascertain whether any causal relationship exists and the direction of the causality (if any is existing) between public expenditures and economic growth in Nigeria.

\section{Literature Review}

\subsection{The Theories}

The Keynesian argument for government interventions in the market is centered on the argument that markets do not always clear as postulated by the classical scholars. The reason is that there are often price and wage rigidities in the short run. The Keynesian theory was propagated at the period when classical economic theory expounded to be incapacitated in the running of the economy. The Keynesians regarded fiscal arrangements of public disbursements as an inspiring element that can be used to stimulate economic growth (Ju-Haung, 2006). In the view of Keynesians, public spending enhances economic undertakings and also act as a tool to stabilize the short run vacillations in the cumulative expenditure. This view is consistent with evidence found in some previous empirical works such as Omoke (2009) which showed a direct impact of public expenditure on the growth of the economy. The Keynesian position advocates for an active public sector interference in the economy through expansions in government expenditures so as to stimulate the demand for goods and services in the periods of demand deficit and put the unemployed back to productive activities. This is pointing at the importance of total demand in determining the level of productivity and returns in an economy. This theory further argued that market economies had no automatic capacity to create full employment, and that the economic policy should be inextricably linked to social policy (Connor \& Simpson, 2011).

Price and wage rigidities will make firms not to sell all the inventory of goods and services they have already wrought and this will be leading to the accumulation of unsold inventory. Therefore, in periods when demand is at a low level, the government should increase its spending (infusing new purchasing power) into the economy so as to accelerate aggregate demand and thereby output through spillover effects. Therefore, activities of the fiscal policy have positive influence on the growth of a country's economy. A rise in public expense will enhance productivity and reduce unemployment in the economy through the spillover effects. Hence the Keynesians' resolve that expansion of public spending increases the national output of a country.

Wagner's Law otherwise known as the Theory of Increasing State Activities progressed a step further in law of escalating public spending by bearing in mind the trends in the growth of public expenditures and in the size of public subdivision. The law states that:

i. The widening of the duties or responsibilities of the public sector especially with the case of unindustrialized economies amounts to an upsurge in public expenditures on administration, and direction of the economy, and others. 
ii. The quest for industrial development by each economy will bring about growing political concentration for social development and by this means call for ungraded consent for social contemplation in the operation of businesses.

iii. The increase in public expenditures will be comparatively more than the increase in the national income and by itself will generate a relative development of the public sector. In support of Wagner's law, Musgrave and Peggy (1973) in their opinion stressed that as progressive countries industrializes, the portion of the section of the public sector in the domestic economy develops enormously.

As a consequence of Musgrave's consideration on the changes in income elasticity of demand for public goods in relation to income per capita, Musgrave's theory considered changes in demand for public goods which brings about public spending in three scales of income per capita. He opined that the demand for public goods at the low levels of per capita income tends to be very low. This he confirmed by emphasizing that at this level, income as such is committed to fulfilling crucial needs which would have been provided by the government. Therefore, government expenditures, he emphasized, will be relatively low when income per capita starts to rise above these levels of low income. The consequences are that the demand for health, education, and transport and other services provided by the public sector will start to rise thus persuading the public sector to step up their disbursements. At a higher level of income per capita (especially of industrialized economies) the rate of growth of the public sector inclines to decrease as more basic needs are being attained and the economy moving from the public sector driven to private sector driven.

\subsection{Review of Previous Related Studies}

Chude and Chude (2013) utilizing Error correction model, scrutinized the long and short run effects of public expenditures on the growth of output in Nigeria and found out that government spending has a highly statistical significant impact on educational sector; and that it has a positive relationship with output growth in the long run.

Jibao, Schoeman, and Naraidoo (2012) applied linear cointegration in the test of asymmetry relationship between the fiscal policy tools (revenue and expenditures) in South Africa. They confirmed that the fiscal policy tools were workable; however, the public institutions in South Africa tended to react faster when the budget was in deficit than in surplus. They also discovered that the stabilization measures by government were fairly unbiased at low deficit levels; specifically at quarterly deficit levels of 4\% of GDP and below.

Onodugo et al. (2017) adopted Ordinal Least Square technique to establish the impact of public expenditures private investment on unemployment in Nigeria. The study established that public capital spending and private sector investment both in the medium to long-run served as catalyst towards reduction of unemployment. On the contrary, public recurrent expenditure was not statistically strong enough to do same as the former. The study therefore recommended, inter-alia, that: the share of public capital expenditures in Nigerian budget profile should be steadily enlarged, while the public recurrent expenditure be reduced; and there is need to enthrone healthy rivalry amongst investors by eliminating structural and institutional rigidities; and governments should design clear policy incentives to private sector investment.

Usman, Mobolaji, Kilishi, Yaru, and Yakubu (2011) using Vector Error Correction Model in their study in an attempt to ascertain the relationship between public spending and economic growth in Nigeria. They found that there exist a long-run relationship between public spending and economic growth.

Devarajan and Vinaya (1993) adopted panel data as a technique to investigate 14 developed countries for a period ranging from 1970 to 1990, and later applied Ordinary Least Square method on 5 year moving average taking varieties of functional types of expenditures (namely: health, education, transport etc.) as explanatory variables. They found out that health, transport and communication have significant direct effect while education and defence inverse impacts on growth.

Bleaney, Gemmell, and Kneller (2001) using panels of annual and period-averaged data for 22 for Organization for Economic Co-operation and Development (OECD) countries during 1970 to 1995, analyzed the impact of public spending on economic growth. Applying OLS and GLS methods, the study discovered that productive public expenditures enhance economic growth, while the non-productive does not, in accordance with the predictions of Barro (1990) model.

Gemmell and R. (2001) provided empirical evidence on the impact of fiscal policy tools on long run growth of the economy of Europe. Their study required that at least two of the taxation/ expenditure/ deficit effects must be examined simultaneously hence they employed panel and time series econometric techniques, including dealing with the endogeneity of fiscal policy tools. Their results showed that while some public sector investments impact positively on economic growth, consumption and social security spending have zero or negative growth effects.

Abu-Bader and Abu-Qarn (2003) employed multivariate co-integration and variance decomposition approach to examine the causal relationship between government expenditures and economic growth for Egypt, Israel, and Syria. In the bivariate framework, the authors observed a bi-directional (feedback) and long run negative relationships between government spending and economic growth. The causality test within the trivariate framework illustrates that military burden has a negative impact on economic growth in all the countries studied. 
Loizides and Vamvoukas (2005) employed the trivariate causality test to investigate the relationship between public expenditures and economic growth using data set from Greece, United Kingdom and Ireland. They found that government size Granger causes economic growth in all the countries studied. The result also indicates that economic growth Granger causes public expenditure for Greece and United Kingdom when inflation is included.

Jiranyakul and Brahmasrene (2007) analyzed the connection between public expenditures and economic growth in Thailand by employing the Granger Causality Tests. The results reveal that government expenditures and economic growth are not co-integrated. Moreover, the results indicate a unidirectional causation as causality runs from public expenditures to growth. The result also illustrates a significant positive effect of government spending on economic growth.

Liu, Hsu, and Younis (2008) examined the causal relationship between GDP and public expenditures for the United States of America using data running from the period 1947 to 2002. The results revealed that total government expenditure causes growth of GDP. On the other hand, growth of GDP does not cause expansion of government expenditure.

Gregoriou and Ghosh (2007) used heterogeneous panel to investigate the impact of government expenditure on economic growth. The authors employed the GMM technique and discovered that economies with large government expenditures tend to experience higher growth.

Devarajans, Swaroop, and Zou (1996) studied the relationship between the compositions of public expenditures and economic growth for a group of developing economies. The regression results shows that public capital spending has a significant inverse relationship with growth of real GDP per capita while public recurrent spending is directly related with real GDP per capita.

Ojong, Nkamare, and Anthony (2016) analyzed government expenditures and its implications on the Nigerian economy using the Ordinary Least Squares technique. Findings from the analysis revealed that recurrent and aggregate expenditures have direct influence on the Nigerian economy. It recommended on the basis of the findings that governments should spend more on security as this is likely to promote investment among others.

Mutiu and Olusijibomi (2013) using Gregory-Hansen structural breaks cointegration techniques uphold Wagner's law in two models in the long run, and exposed that economic development and growth are the major purpose of government spending. With particular reference to the areas of infrastructure and human capital, and all of which that falls under social and community services.

\subsection{Model Specification}

This study adopted Keynesian model of growth as its theoretical framework. This theory states that fiscal arrangements of public disbursements acts as an inspiring element which can be used to stimulate and accelerate economic growth. To the Keynesians, public spending boosts economic activities as well as act as a tool to stabilize the short run fluctuations in aggregate expenditure (Ju-Haung, 2006). Keynes (1936) regards public expenditures as an exogenous factor which can be utilized as a policy instrument to promote economic growth. Hence, an increase in government consumption is likely to provoke an improvement in in macroeconomic indicators.

The Keynesian output composition model is captured by:

$$
\mathrm{Y}=\mathrm{C}+\mathrm{I}+(\mathrm{X}-\mathrm{M})
$$

Where:

$\mathrm{Y}$ is Output

$\mathrm{C}$ is consumption

$\mathrm{I}$ is investment

$(\mathrm{X}-\mathrm{M})$ is the current account balance.

The modification of the model helped to investigate the impact of public expenditure on economic growth. Therefore: Y = Real Gross Domestic Product (RGDP) as a proxy for output. To further suit the theoretical context and the relevance of this study, we modified the model to accommodate public expenditures disaggregated into public capital expenditure (PCEXP) and public recurrent expenditure (PRECEXP), private foreign investment (PFI) and exchange rate (EXR).

The modified model therefore expresses economic growth (Real GDP) as a function of public capital expenditure, public recurrent expenditure, private foreign investment and exchange rate. Thus, specified in its functional form as follows:

$$
\text { RGDP }=\mathrm{f}(\text { PCEXP, PRECEXP, PFI, EXR })
$$

Where:

RGDP = Real Gross Domestic Product (Proxy for economic growth)

PCEXP = Public Capital Expenditure

PRECEXP = Public Recurrent Expenditure

$\mathrm{PFI}=$ Private Foreign Investment

$\mathrm{EXR}=$ Exchange Rate

The linear function of the model is presented as follows: 
$\mathrm{RGDP}_{\mathrm{t}}=\pi_{\mathrm{o}}+\pi_{1} \mathrm{PCEXP}_{\mathrm{t}}+\pi_{2} \mathrm{PRECEXP}_{\mathrm{t}}+\pi_{3} \mathrm{PFI}_{\mathrm{t}}+\pi_{4} \mathrm{EXR}_{\mathrm{t}}+\varepsilon_{\mathrm{t}}$

Where:

$\pi_{0}=$ Constant term

$\pi_{1}=$ Regression coefficient for Public Capital Expenditure

$\pi_{2}=$ Regression coefficient for public recurrent expenditure

$\pi_{3}=$ Regression coefficient for Private Foreign investment

$\pi_{4}=$ Regression coefficient for Exchange Rate

$\varepsilon=$ Stochastic Error Term

$\mathrm{t}=$ Time series

$\pi_{1,} \pi_{2}, \pi_{3,}>0, \pi_{4}<0$

The model (3) (save EXR which is in its real value) is however transformed into log linear model to enable the study standardize all values and interpret the variables coefficients as elasticities as specified below:

LRGDP $_{t}=\pi_{0}+\pi_{1}$ LGPCEXP $_{t}+\pi_{2}$ LGRECEXP $_{t}+\pi_{3}$ LGPFI $_{t}+\pi_{4}$ EXR $_{t}+\varepsilon_{t}$

The sample period for the study covers 1980 to 2016 and annual data were extracted from Central Bank of Nigeria (CBN) Statistical Bulletin and the National Bureau of Statistics (NBS) documents.

\section{Analysis of Results}

We conducted Augmented Dickey-Fuller (ADF) test. The results revealed that all the variables are integrated of order one 1(1) (differenced once to attain stationarity). In other words, all the variables have unit roots, but stationary after being differenced. This is because the ADF statistic for each of the variables is less than the critical levels at $5 \%$. In other words, the null hypothesis for unit root is accepted for all the variables at the level form. On the other hand, the ADF statistics for each of the variables when differenced are higher than their critical values at 5\% which implies that the null hypothesis of unit root is rejected.

Co-integration test indicates that co-integration does exist since the value of the computed statistic exceeds the $5 \%$ critical values in the null hypothesis for both Trace and Maximum Eigen values tests criteria (indicating two co-integrating equations). Therefore, there is long run relationship between Real GDP and the explanatory variables (PCEXP, PRECEXP, PFI, and EXR).

The Error Correction Model (ECM) indicates that the t-statistic for public capital expenditure is above the ' $2 \mathrm{t}$ ' thumb rule (-3.206054) and the coefficient is -0.278534 . This implies that public capital expenditure has a significant negative impact on economic growth (RGDP). This also implied that a $1 \%$ increase in public capital expenditure results in $0.278534 \%$ decrease in RGDP. This negates economic a priori expectation.

Public recurrent expenditure has a t-statistic value of 1.332026 and coefficient value of 0.171596 . This implies that public recurrent expenditure has an insignificant positive impact on RGDP (economic growth). This also implied that a $1 \%$ increase in public recurrent expenditure would result in $0.171596 \%$ increase in real GDP (economic growth). The positive impact is in conformity with economic a priori expectation. However the impact is not statistically significant. The causes of these results may be not be found far from and can be attributed to complacency and the systemic endemic corruption in Nigeria where diversion of public funds to personal and other uses has been a worrisome issue.

Foreign private investment and exchange rate have insignificant impact on RGDP (economic growth) with t-statistic values of 0.340206 and -0.353427 respectively. Therefore a $1 \%$ increase in foreign private investment would result in $0.037785 \%$ increase in economic growth (RGDP). This is in conformity with a priori expectation. Correspondingly, exchange rate (in conformity with a priori expectation) has a negative impact on economic growth as $1 \%$ increase in exchange rate would results in $0.000880 \%$ decrease in economic growth. The impact of the key variables (public capital expenditures and public recurrent expenditures) on Real GDP is in agreement with Devarajans et al. (1996) whose regression results on a group of developing countries show that capital expenditure has significant negative association with growth, Real GDP per capita while recurrent expenditure is positively related to Real GDP per capita.

The Error Correction Model result also depicts the ECM as rightly signed and statistically significant with coefficient of -0.977765 and $t$ - statistic value of -8.932139 . The implication of this is that $97 \%$ disequilibrium in economic growth (RGDP) in the short run can be corrected by the specified independent variables (PCEXP, PRECEXP, PFI, and EXR) in the long run.

The $\mathrm{R}$ squared $\left(\mathrm{R}^{2}\right)$ value of 0.765327 indicates that about $77 \%$ variation in RGDP is explained by the explanatory variables while the $\mathrm{F}$-statistic of 18.26 which is above the critical $\mathrm{F}$-value of 8.32 implies that the entire variables in the model joined together are significantly different from zero.

The Granger causality test indicates that there is no causal relationship between PCEXP and economic growth (RGDP), and that a unidirectional causality exists between PRECEXP, PFI, EXR and economic growth. The results showed that EXR caused RGDP to change; RGDP caused PFI to change; and RGDP caused PRECEXP to change. This is at variance with the findings of Liu et al. (2008) on the economy of the United States of America whose causality results revealed that total government expenditure causes growth of gross domestic product. 


\section{Summary of Findings}

(i) The Error Correction Model estimates indicate that the ' $t$ ' values for public capital expenditure and public recurrent expenditure are -3.206054 and 1.332026 respectively. While public capital expenditure is statistically significant in determining economic growth (real GDP), public recurrent expenditure is not statistically significant. However, the ' $t$ ' values for private foreign investment and exchange rate were 0.34 and -0.35 respectively indicating that they are statistically insignificant in determining economic growth in Nigeria.

(ii) The coefficients for the independent variables - public capital expenditure, public recurrent expenditure, private foreign investment and exchange rate are $-0.28,0.17,0.038$ and -0.00088 respectively.

(iii) The Granger Causality test reveals that the probability values of the hypothesized relations between Real GDP and public capital expenditure are above 0.05. The causal relationship from Real GDP to public recurrent expenditure has a probability value below $0.05(0.0235)$ while the probability value for the causal relationship from public recurrent expenditure to real GDP is 0.6818 which is above 0.05 .

\section{Conclusion}

From the summary of findings, the study concludes as follows:

i. Public Capital expenditure has a significant negative impact on economic growth. This means that a $1 \%$ increase in public capital expenditure results in $0.28 \%$ decrease in economic growth. However, public recurrent expenditure has an insignificant positive impact on economic growth. $1 \%$ increase in recurrent expenditure leads to $0.17 \%$ increase in economic growth.

ii. The probability values of 0.5423 and 0.3159 indicates that public capital expenditure do not cause Real GDP (economic growth) and real GDP do not also cause public capital expenditure. There is therefore no causal relationship between both variables. Public recurrent expenditure does not cause real GDP, while real GDP causes public recurrent expenditure. There is therefore a uni-directional causal relationship between public recurrent expenditure and real GDP.

\section{Recommendations}

From the conclusion of the study, the following recommendations are put forth:

i. Governments should make more provision for capital expenditure in the budget and monitor its implementation to curb corruptions and diversion of funds to other uses. This is in view of the fact that $1 \%$ increase in public capital expenditure leads to $0.28 \%$ decrease in economic growth which negates economic a priori expectation.

ii. The public recurrent expenditure estimation result indicates that a $1 \%$ increase results in $0.17 \%$ increase in economic growth. This result meets a priori expectation but its impact is not statistically significant. Therefore, governments should strive to reduce the cost of governance as part of measures to reduce public recurrent expenditure while making more provision for public capital expenditure whose proper implementation is strategic for boosting infrastructural and productive capacity in the economy, generate employment amongst others and ultimately increase economic growth.

\section{References}

Abu-Bader, S., \& Abu-Qarn, A. S. (2003). Government expenditures, military spending and economic growth: causality evidence from Egypt, Israel, and Syria. Journal of Policy Modeling, 25(6-7), 567-583.

Adubi, A. A., \& Obioma, E. C. (1999). Public expenditure management in Nigeria, edited by Komolafe, O. S; Jalilian, H, and Hiley, M. in Fiscal Policy Planning and Management in Nigeria. Ibadan: NCEMA.

Barro, R. J. (1990). Government spending in a simple model of endogeneous growth. Journal of Political Economy, 98(5, Part 2), S103-S125.

Bleaney, M., Gemmell, N., \& Kneller, R. (2001). Testing the endogenous growth model: Public expenditure, taxation, and growth over the long run. Canadian Journal of Economics, 34(1), 36-57.

Chude, N. P., \& Chude, D. I. (2013). Impact of government expenditure on economic growth in Nigeria. International Journal of Business and Management Revierw, 1(4), 64-71.

Connor, S., \& Simpson, G. (2011). Social policy for social welfare professionals: Tools for understanding, analysis, and engagement. Bristol, UK: The Policy Press.

Cooray, A. (2009). Government expenditure, governance and economic growth. Comparative Economic Studies, $51(3)$, 401418.

Devarajan, S., \& Vinaya, S. (1993). What do governments buy? The composition of public spending and economic performance. Policy Research Working Paper, WPS 1082. The World Bank.

Devarajans, S., Swaroop, V., \& Zou, H.-f. (1996). The composition of public expenditure and economic growth. Journal of Monetary Economics, 37(2), 313-344.

Engen, E. M., \& Skinner, J. (1992). Fiscal policy and economic growth, national bureau of economic research, Working paper series No 4223. Retrieved from www.nber.org/papers/w4223pdf.

Gemmell, N., \& R., K. (2001). The impact of fiscal policy on long run growth. London: European Economy Press. 
Gregoriou, A., \& Ghosh, S. (2007). The impact of government expenditure on growth: Empirical evidence from heterogeneous panel. Retrieved from http://www.brunel.ac.uk/9379/efwps/0701.pdf.

Jibao, S. S., Schoeman, N. J., \& Naraidoo, R. (2012). Fiscal regime changes and the sustainability of fiscal imbalance in South Africa: A smooth transition error-correction approach. South African Journal of Economic and Management Sciences, 15(2), 112-127.

Jiranyakul, K., \& Brahmasrene, T. (2007). The relationship between government expenditures and economic growth in Thailand. Journal of Economics and Economic Education Research, 8(1), 93-102.

Ju-Haung, C. (2006). Government expenditures in China and Taiwan: Do they follow Wagner's law? Journal of Economic Development, 3(2), $139-148$.

Keynes, J. M. (1936). The general theory of employment, interest and money. New York: Brace and Co.

Ladau, D. (1983). Government expenditure and economic growth: A cross country study. Southern Economic Journal, 49(3), 783-792.

Liu, L. C.-h., Hsu, C. E., \& Younis, M. Z. (2008). The association between government expenditure and economic growth: Granger causality test of US data, 1947-2002. Journal of Public Budgeting, Accounting ङ Financial Management, $20(4), 439-452$.

Loizides, J., \& Vamvoukas, G. (2005). Government expenditure and economic growth: Evidence from trivariate causality testing. Journal of Applied Economics, 8(1), 125-152.

Musgrave, R. A., \& Peggy, B. M. (1973). Public finance in theory and practice. New York: McGraw-Hill Book Company.

Mutiu, A. O., \& Olusijibomi, A. (2013). Public expenditure and economic growth nexus: Further evidence from Nigeria. Journal of Economic and Internatinal Finance, 5(4), 146-154. Available at: https://doi.org/10.5897/JEIF2013.0489.

Obinna, O. E. (1985). Public finance. Nsukka: AP and P Press Ltd.

Ogunmuyiwa, M. S., \& Adelowokan, O. (2015). Measuring the impact of public expenditure on economic growth in Nigeria. Journal of Social Science Studies, 2(2), 46-55.

Ojong, C. M., Nkamare, S., \& Anthony, O. (2016). Government expenditure and its implications on Nigerian economy. IOSR Journal of Humanities and Social Science, 21(1), 50-55.

Okorie, G. C., \& Anowor, O. F. (2017). Empirical appraisal of poverty-unemployment relationship in Nigeria. International Journal of Economics and Financial Research, 3(6), 91-97.

Okoro, A. S. (2013). Government spending and economic growth of Nigeria (1980-2011). Global Journal of Management and Business Research, Economics and Commerce, 13(5), $20-30$.

Omoke, C. P. (2009). Government expenditure and national income: A causality test for Nigeria. European Journal of Economic and Political Studies, 2(2), 1-12.

Onodugo, V. A., Obi, K. O., Anowor, O. F., Nwonye, N. G., \& Ofoegbu, G. N. (2017). Does public spending affect unemployment in an emerging market. Risk Governance \& Control: Financial Markets \& Institutions, 7(1), 32-40.

Ranjan, K., \& Sharma, C. (2008). Government expenditure and economic growth: Evidence from India. The ICFAI University Journal of Public Finance, 6(3), 60-69.

Usman, A., Mobolaji, H., Kilishi, A., Yaru, M., \& Yakubu, T. (2011). Public expenditure and economic growth in Nigeria. Asian Economic and Financial Reviere, 1(3), 104-113. 